\title{
Research and Practice of the Early Stage Polymer Flooding on LD Offshore Oilfield
}

Kuiqian Ma, Yanlai Li, Ting Sun*

China National Offshore Oil Corporation (CNOOC) Ltd., Tianjin, China University of Petroleum-Beijing, P.R. China

\begin{abstract}
Literature survey shows that polymer flooding was generally conducted during high water-cut stage (WCT>80\% to $90 \%$ ). Even the first China Offshore polymer flooding project was carried out in SZ when water cut was $60 \%$. By then, conduction of polymer flooding in early phase (WCT<10\%) was just discussed in theory. For offshore oilfield, the treatment of water could be costly. Because polymer improves mobility ratio of replacement fluid over oil and sweep efficiency, less water is injected and less water is produced. So, we did enormous research about the polymer flooding on early stage by theoretical analysis, series of experiments and chemical flooding simulation. Based on these researches, we carried out the first field test of polymer flooding on early stage in LD. Single well polymer injection test was started in Mar 2006 when the water cut in the pattern was lower than $10 \%$. After the trial, there were other 5 water injectors being converted to polymer injectors from 2007 to 2009 . The polymer flooding controlled reserve was about $25,250,000 \mathrm{~m}^{3}$. For the early stage polymer flooding, the characteristics of the responses on producers were different from the case in which polymer flooding was conducted during high water cut stage. The water producing of the producers continued to rise up after polymer flooding, but the simulation research showed that the water cut increasing rate was lower than the rate during merely water flooding. In addition, we observed the drop-down on the water cut in some wells, such as A11, A12, A13, A15, etc. For the well A11, the highest water cut reduction reached $41 \%$ after the injectors (A5/A10) profiles controlled, and net incremental oil for A11 even reached $154,510 \mathrm{~m}^{3}$. By Dec 2014, the total incremental oil by polymer flooding was about $754,650 \mathrm{~m}^{3}$, and the stage oil recovery efficiency was enhanced by $3.0 \%$. The polymer flooding is still effective, and we will get more oil from the polymer flooding.
\end{abstract}

Keywords: EOR; Polymer Flooding; Offshore oil field

Abbreviations: RRF: Residual Resistance Factor; RF: Resistance Factor; PORFT: Accessible Pore Volume; FREQFAC: Reaction Frequency Factor; ADMAXT: Maximum Adsorption Capacity; ADRT: Residual Adsorption Level; PI: Pressure Index; WCT: Water Cut.

\section{Introduction}

With the improvement of offshore exploration extent, there are more and more heavy oil found. The oil recovery was only $18 \%$ to $25 \%$ by the conventional oil production method of water injection. So more challenges rise up, such as how can we get more oil? How can we improve the oil recovery? For the offshore oilfield, a method which can be used to develop oilfield more efficiently must be found due to the life time of offshore platform is limited (with the life of 25 years to 30 years).

Polymer flooding was already a mature set of technology to improve oil recovery on the onshore oilfields in China. Literature survey shows that polymer flooding was generally carried out during high water-cut stage (WCT $>80 \%$ to $90 \%$ ). Even the first China Offshore polymer flooding project was carried out in SZ when water cut was 60\%. By then, conduction of polymer flooding in early phase (WCT $<10 \%)$ was just discussed in theory. So, we did enormous research about the polymer flooding on early stage by theoretical analysis, series of experiments and chemical flooding simulation, as shown in (Figures 1 and 2). Gel

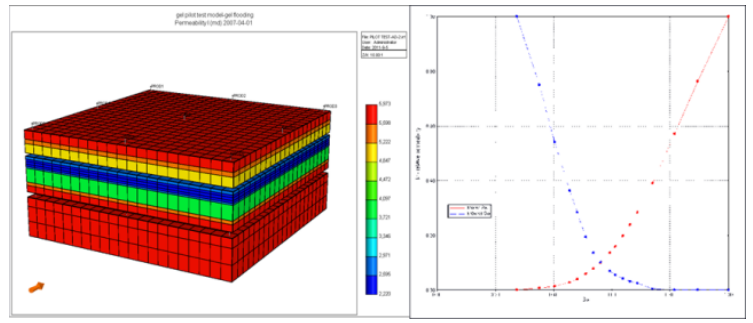

Figure 1: The numerical simulation of the mechanism research.

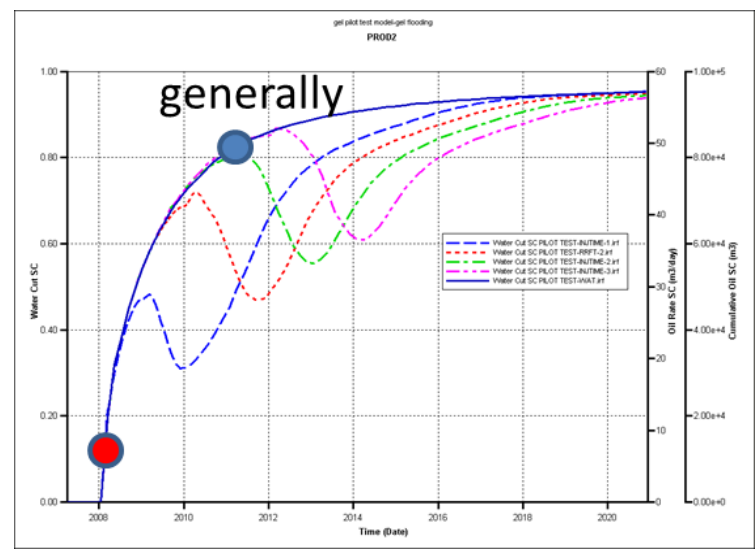

Figure 2: The EOR in different time.

flooding technology combines the function of improvement of mobility ratio by polymer flooding and injection profile control by cross linked gel injection.

LD oilfield is located in Bohai Bay, characterized by huge thickness,

"Corresponding author: Ting sun, Institute for Ocean Engineering, China University of Petroleum-Beijing, China, Tel: 86-10-89731669 E-mail: ting.sun@cup.edu.cn

Received April 24, 2017; Accepted July 31, 2017; Published August 07, 2017

Citation: Kuiqian Ma, Yanlai Li, Ting Sun (2017) Research and Practice of the Early Stage Polymer Flooding on LD Offshore Oilfield. J Pet Environ Biotechnol 8: 337. doi: 10.4172/2157-7463.1000337

Copyright: () $2017 \mathrm{Ma}$ et al.. This is an open-access article distributed under the terms of the Creative Commons Attribution License, which permits unrestricted use, distribution, and reproduction in any medium, provided the original author and source are credited. 


\begin{tabular}{|c|c|c|c|c|c|}
\hline $\begin{array}{c}\text { Method of } \\
\text { displacement }\end{array}$ & $\begin{array}{l}\text { The water cut start to the polymer } \\
\text { injection (\%) }\end{array}$ & $\begin{array}{l}\text { Viscosity of the } \\
\text { oil (cp) }\end{array}$ & $\begin{array}{l}\text { Polymer concentration } \\
\text { (mg/l) }\end{array}$ & Core size & Other lab test conditions \\
\hline \multirow{4}{*}{ Polymer } & 0 & \multirow{5}{*}{70} & \multirow{5}{*}{1750} & \multirow{5}{*}{$\begin{array}{c}\mathrm{L}: 30 \mathrm{~cm} \\
\mathrm{~W}: 4.5 \mathrm{~cm} \mathrm{H}: 4.5 \\
\mathrm{~cm}\end{array}$} & \multirow{5}{*}{$\begin{array}{c}\text { Temperature: } 65^{\circ} \mathrm{C} \\
\text { Rate of displacement: } 1 \mathrm{~m} / \mathrm{d} \\
\text { Polymer injection PV: } 0.25 \mathrm{PV}\end{array}$} \\
\hline & 28 & & & & \\
\hline & 53 & & & & \\
\hline & 97 & & & & \\
\hline Water & -- & & & & \\
\hline
\end{tabular}

Table 1: The geometric parameters of the model.

\begin{tabular}{|c|c|c|c|c|}
\hline Method of displacement & $\begin{array}{l}\text { The water cut start to the } \\
\text { polymer injection (\%) }\end{array}$ & $\begin{array}{l}\text { The water flood recovery before } \\
\text { polymer flood (\%) }\end{array}$ & $\begin{array}{l}\text { The ultimate recovery } \\
\text { factor }(\%)\end{array}$ & $\begin{array}{l}\text { Improve oil recovery by } \\
\text { polymer flooding (\%) }\end{array}$ \\
\hline \multirow{4}{*}{ Polymer } & 0 & 0 & 51.35 & 6.23 \\
\hline & 28 & 22.2 & 51.08 & 5.96 \\
\hline & 53 & 23.1 & 50.75 & 5.63 \\
\hline & 97 & 45.1 & 50.35 & 5.23 \\
\hline
\end{tabular}

Table 2: The results of lab test experiments.

\begin{tabular}{|c|c|c|c|c|c|c|}
\hline $\begin{array}{c}\text { The water cut start to the polymer } \\
\text { injection (\%) }\end{array}$ & $\mathbf{0}$ & $\mathbf{2 0}$ & $\mathbf{4 0}$ & $\mathbf{6 0}$ & $\mathbf{8 0}$ \\
\hline $\mathrm{Rw}(\%)$ & \multicolumn{5}{|c|}{39.86} \\
\hline $\mathrm{Rp}(\%)$ & 49.28 & 48.98 & 48.73 & 48.3 & 46.71 \\
\hline$\Delta \mathrm{R}(\%)$ & 9.39 & 9.09 & 8.84 & 8.42 & 6.82 \\
\hline
\end{tabular}

Table 3: Statistical recovery efficiency in the development of 30 years.

\begin{tabular}{|c|c|c|c|c|c|}
\hline \multicolumn{6}{|c|}{ The polymer } \\
\hline Polymer concentration (mg/L) & 500 & 700 & 1000 & 1200 & 1500 \\
\hline Polymer viscosity (cp) & 3.5 & 4.5 & 6 & 8 & 9.5 \\
\hline \multicolumn{6}{|c|}{ The cross-linked polymer $\left(\mathrm{P}: \mathrm{Cr}^{3}=60: 1\right)$} \\
\hline Polymer concentration (mg/L) & 500 & 700 & 1000 & 1200 & 1500 \\
\hline Polymer viscosity (cp) & 3 & 4 & 5.5 & 7 & 8.5 \\
\hline
\end{tabular}

Table 4: The relationship between viscosity and concentration of gel and polymer.

\begin{tabular}{|c|c|c|c|c|c|}
\hline \multirow{2}{*}{ Polymer concentration (P: $\mathbf{C r}^{3}$ ) } & \multicolumn{5}{|c|}{ Viscosity of the crosslinked polymer (cp) } \\
\cline { 3 - 6 } & Initial & $\begin{array}{c}\text { After } \\
\text { 2 days }\end{array}$ & $\begin{array}{c}\text { After 5 } \\
\text { days }\end{array}$ & $\begin{array}{c}\text { After 10 } \\
\text { days }\end{array}$ & $\begin{array}{c}\text { After 15 } \\
\text { days }\end{array}$ \\
\hline $1200 \mathrm{mg} / \mathrm{L},\left(\mathrm{P}: \mathrm{Cr}^{3}=40: 1\right)$ & 8.2 & 420 & 582.3 & 613 & 602.3 \\
\hline $1200 \mathrm{mg} / \mathrm{L},\left(\mathrm{P}: \mathrm{Cr}^{3}=60: 1\right)$ & 8.1 & 312 & 452.3 & 523 & 572.3 \\
\hline $1000 \mathrm{mg} / \mathrm{L},\left(\mathrm{P}: \mathrm{Cr}^{3}=60: 1\right)$ & 5.9 & 62.9 & 87.5 & 137 & 210.5 \\
\hline $1000 \mathrm{mg} / \mathrm{L},\left(\mathrm{P}: \mathrm{Cr}^{3}=40: 1\right)$ & 6.2 & 154 & 231.4 & 336 & 341.2 \\
\hline
\end{tabular}

Table 5: The viscosity of the cross-linked polymer.

\begin{tabular}{|c|c|c|c|c|}
\hline $\begin{array}{c}\text { Core } \\
\text { number }\end{array}$ & 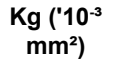 & Displacement system & RF & RRF \\
\hline R3-9 & 1350 & $\begin{array}{l}\text { The crosslinked polymer } \mathrm{Cp}=1200 \mathrm{mg} / \mathrm{l}(\mathrm{P}: \\
\left.\qquad \mathrm{Cr}^{3^{+}}=20: 1\right)\end{array}$ & 45.6 & 58.2 \\
\hline $12-4-5$ & 1355 & $\begin{array}{l}\text { The crosslinked polymer } \mathrm{Cp}=1200 \mathrm{mg} / \mathrm{l}(\mathrm{P} \text { : } \\
\qquad \mathrm{Cr}^{\left.3^{+}=40: 1\right)}\end{array}$ & 39.9 & 48.4 \\
\hline $12-3-5$ & 1360 & $\begin{array}{l}\text { The crosslinked polymer } \mathrm{Cp}=1200 \mathrm{mg} / \mathrm{l}(\mathrm{P}: \\
\left.\qquad \mathrm{Cr}^{3^{+}}=60: 1\right)\end{array}$ & 34.9 & 39.3 \\
\hline L12-1-1 & 1345 & $\begin{array}{l}\text { The crosslinked polymer } \mathrm{Cp}=1200 \mathrm{mg} / \mathrm{l}(\mathrm{P} \text { : } \\
\left.\qquad \mathrm{Cr}^{3^{+}}=80: 1\right)\end{array}$ & 32.9 & 35.6 \\
\hline $12-4-2$ & 1320 & $\begin{array}{l}\text { The crosslinked polymer } \mathrm{Cp}=800 \mathrm{mg} / \mathrm{l}(\mathrm{P} \text { : } \\
\left.\qquad \mathrm{Cr}^{3+}=20: 1\right)\end{array}$ & 38.9 & 46.7 \\
\hline $12-3-4$ & 1380 & $\begin{array}{l}\text { The crosslinked polymer } \mathrm{Cp}=800 \mathrm{mg} / \mathrm{l}(\mathrm{P} \text { : } \\
\left.\qquad \mathrm{Cr}^{3+}=40: 1\right)\end{array}$ & 33.9 & 42.9 \\
\hline L12-1-2 & 1346 & $\begin{array}{l}\text { The crosslinked polymer } \mathrm{Cp}=800 \mathrm{mg} / \mathrm{l}(\mathrm{P} \text { : } \\
\left.\qquad \mathrm{Cr}^{3+}=60: 1\right)\end{array}$ & 29.9 & 36.3 \\
\hline $12-4-10$ & 1368 & Polymer $\mathrm{Cp}=800 \mathrm{mg} / \mathrm{l}$ & 12.9 & 1.8 \\
\hline $12-4-10$ & 1349 & Polymer $\mathrm{Cp}=1000 \mathrm{mg} / \mathrm{l}$ & 16.2 & 2.5 \\
\hline $12-4-13$ & 1342 & Polymer $\mathrm{Cp}=1200 \mathrm{mg} / \mathrm{l}$ & 21.3 & 3.2 \\
\hline
\end{tabular}

Table 6: The RF and RRF of the cross-linked polymer. high permeability, severe heterogeneity, high crude oil density $(0.947 \mathrm{~g} /$ $\mathrm{cm}^{3}$ ) and medium oil viscosity (7.2 $\mathrm{cp}$ to $19.4 \mathrm{cp}$ ). LD oilfield was put online in January of 2005, and started to inject water on September of 2005. Based on well understanding of the mechanism and effect of the early polymer flooding, we carried out the single well polymer injection pilot test from 2006 when the water cut in the pattern was lower than $10 \%$. After the trial, there were other 5 water injectors were converted to polymer injectors from 2007 to 2009. The polymer flooding controlled reserve was about $25,250,000 \mathrm{~m}^{3}$. For the early stage polymer flooding, the characteristics of the responses on producers were different from the case in which polymer flooding was conducted during high water cut stage. The water producing of the producers continued to rise up after polymer flooding, but the simulation research showed that the water cut increasing rate was lower than the rate during merely water flooding. Of course, we also observed the drop down on the water cut in some wells, such as A11, A12, A13, A15, etc. For the well A11, the highest water cut reduction reached $41 \%$ after the injectors (A5/ A10) profiles controlled, and net incremental oil for A11 even reached $154,510 \mathrm{~m}^{3}$. By December 2014, the total incremental oil by polymer flooding was about $754,650 \mathrm{~m}^{3}$, and the stage oil recovery efficiency was enhanced by $3.0 \%$. The polymer flooding is still effective, and we will get more oil from the polymer flooding.

\section{Experiment Tests and Polymer Flooding Scheme Design}

\section{Mechanism study on early stage polymer flooding}

Geometric size of the core model is $30 \mathrm{~cm} \times 4.5 \mathrm{~cm} \times 4.5 \mathrm{~cm}$, and the parameters of experiments were shown in Tables 1 and 2). The results of lab test experiments were shown in Table 2. From the results of the lab test, the difference of the EOR between cases in which polymer flooding conducted at different time was not obvious. But for offshore oilfield, the platform life was about 25 years to 30 years. We must produce more oil in limited time. From numerical simulation of the mechanism research, we know that the larger enhanced recovery value can be obtained, if polymer can be injected earlier (Table 3) [1-3].

\section{Experiment tests and mechanistic models of gel}

The relationship between viscosity and concentration of gel and polymer in early stage was shown in Table 4 . The experiment about the crosslinked polymer viscosity in the case of different polymer concentrations and ratios of the polymer to $\mathrm{Cr}^{3+}$ was done. As is shown in the Table 5, the viscosity also increased with time going by. The results of RF and RRF test were shown in Table 6 . RRF of the polymer 
is 1.8 to 3.2 from the experiment, and the gel is 39.3 . According to the experiment results and the SZ oilfield mature experience, RRF of LD gel is 5 , and the polymer is 2.5 . The static adsorption and dynamic adsorption tests were shown in Tables 7 and 8 .

\section{Injection scheme design}

The size of injection slug was $0.163 \mathrm{PV}$, and the period of the slug injection was 5 years as shown in Table 9. Injection system was the polymer and Chromium ion $\left(\mathrm{Cr}^{3+}\right)$ crosslinking agent. The concentration of the polymer was $1200 \mathrm{mg} / \mathrm{L}$ (Polymer: $\mathrm{Cr}^{3+}=600: 1-$ 60:1). The polymer injection rate was $0.033 \mathrm{PV}$ per year. The predicted improve recovery factor was $6.1 \%$.

\section{The Result of the Field Test}

From March of 2006, the polymer injection trial has been conducted on the A23 well when the water cut of the pattern was lower than $10 \%$. After the trial, there were other 5 injectors (A1\A $\backslash \mathrm{A} 10 \backslash \mathrm{A} 14 \backslash \mathrm{A} 18 \mathrm{M}$ ) were converted to polymer injectors from 2007 to 2009 . The polymer flooding controlled reserve was about $25,250,000 \mathrm{~m}^{3}$.

Characteristic of gel-injection well effectiveness is shown in Figure 3 and Table 10. From the table we can conclude: injecting pressure rise, while water injectivity index decline and the values of RF and RRF remain above 1 .

\begin{tabular}{|c|c|c|}
\hline Number & Polymer concentration (mg/L) & Static adsorption $\mathbf{( m g / g )}$ \\
\hline 1 & 600 & 2.51 \\
\hline 2 & 800 & 2.82 \\
\hline 3 & 1000 & 3.13 \\
\hline 4 & 1200 & 4.31 \\
\hline 5 & 1400 & 5.16 \\
\hline
\end{tabular}

Table 7: The static adsorption experiment result.

\begin{tabular}{|c|c|c|c|}
\hline $\begin{array}{c}\text { Displacement } \\
\text { solution }\end{array}$ & $\begin{array}{c}\text { Core permeability } \\
\left(\mathbf{1 0}^{-3} \mathbf{m m}^{\mathbf{2}}\right)\end{array}$ & $\begin{array}{c}\text { Polymer } \\
\text { concentration } \mathbf{( m g / l )}\end{array}$ & $\begin{array}{c}\text { Dynamic } \\
\text { adsorption }(\boldsymbol{\mu g} / \mathbf{g})\end{array}$ \\
\hline \multirow{2}{*}{ DQKY polymer } & 1096 & 1400 & 126 \\
\cline { 2 - 4 } & 1103 & 1200 & 95 \\
\hline \multirow{2}{*}{ DQGF gel } & 1133 & 1200 & 332 \\
\cline { 2 - 4 } & 1108 & 1000 & 226 \\
\hline \multirow{2}{*}{ DQGF polymer } & 1202 & 1200 & 104 \\
\cline { 2 - 4 } & 1100 & 1000 & 72 \\
\hline
\end{tabular}

Table 8: The dynamic adsorption experiment result.
For the early stage polymer flooding, the characteristics of the responses on producers were different from the case in which polymer flooding was conducted during high water cut stage. The water producing of the producers continued to rise up after polymer flooding, but the simulation research showed that the water cut increasing rate was lower than the rate during merely water flooding (Figures 4-6). Of course, we also observed the drop down on the water cut in some wells, such as A11, A12, A13, A15, etc. For the well A11 (Figure 5), the highest water cut reduction reached $41 \%$ after the injectors (A5/A10) profiles controlled, and net incremental oil for A11 even reached 154,510 $\mathrm{m}^{3}$.

By December 2014, the total incremental oil by polymer flooding was about $754,650 \mathrm{~m}^{3}$, and the stage oil recovery efficiency was enhanced by $3.0 \%$. And the polymer flooding is still effective now, and the polymer will be injecting until 2017. So we will get more oil from the polymer flooding. And the reasonable expectation of recovery beyond 2014 will be $2.8 \%$. Totally we can get the oil recovery enhanced by polymer in LD oil field will be $5.8 \%$. The actual EOR from polymer will be less than the plan of $6.1 \%$ EOR. The reason was that there were some wells blocked by polymer and sand. And we are doing lots works on solving the sand and polymer blockage $[4,5]$.

\section{Discussion and Conclusion}

a. For the offshore oilfield, the platform life was about 25 years to 30 years. From lab test and numerical simulation research, we both know that the larger enhanced recovery value can be obtained, if polymer can be injected earlier.

b. We designed the polymer flooding on early stage, and the field test was carried out on the LD heavy oilfield of China offshore when the water cut was less than $10 \%$.

c. By December 2014, the total incremental oil of polymer flooding was about $754,650 \mathrm{~m}^{3}$, and the stage recovery was improved by $3.0 \%$. The polymer flooding is still effective, and more oil will be produced by the polymer flooding.

\section{Acknowledgment}

The data presented in this paper was obtained from many other departments of CNOOC Ltd -Tianjin, such as the production department and offshore department etc. And the polymer and gel suppliers also provided some laboratory test data. We would like to thank them all for their contributions to this work.

\begin{tabular}{|c|c|c|c|c|c|c|c|}
\hline Injecting slug & $\begin{array}{c}\text { Displacement } \\
\text { pattern }\end{array}$ & $\begin{array}{c}\text { Time } \\
\text { (month) }\end{array}$ & Displacement agent & $\begin{array}{c}\text { Slug concentration } \\
(\mathrm{mg} / \mathrm{L})\end{array}$ & $\begin{array}{c}\text { Mother liquor } \\
\text { concentration }(\mathrm{mg} / \mathrm{L})\end{array}$ & \begin{tabular}{|c|} 
Injecting \\
pressure (Mpa)
\end{tabular} & Implementation date \\
\hline $\begin{array}{c}\text { First slug }(0.0275 \\
\text { PV) }\end{array}$ & Gel & 10 & $\begin{array}{l}\text { DQGF+crosslinking agents } \\
\left(P: \mathrm{Cr}^{3}=600: 1 \sim 60: 1\right)\end{array}$ & 1200 & \multirow{3}{*}{5000 to 6200} & \multirow{3}{*}{$<10$} & \multirow{3}{*}{$\begin{array}{l}\text { The polymer injection trial } \\
\text { was conducted on the A23 } \\
\text { well in March of } 2006 \text {. After } \\
\text { the trial, there were other } 5 \\
\text { injectors were converted to } \\
\text { polymer injectors from } 2007 \\
\text { to } 2009 \text {. }\end{array}$} \\
\hline $\begin{array}{c}\text { Second slug }(0.11 \\
\text { PV) }\end{array}$ & Polymer & 40 & DQKY & 1600 & & & \\
\hline $\begin{array}{c}\text { Third slug }(0.0275 \\
\text { PV })\end{array}$ & Gel & 10 & $\begin{array}{l}\text { DQGF+crosslinking agents } \\
\quad\left(P: C r^{3}=600: 1-60: 1\right)\end{array}$ & 1200 & & & \\
\hline
\end{tabular}

Table 9: The dynamic adsorption experiment result.

\begin{tabular}{|c|c|c|c|c|c|c|c|}
\hline \multicolumn{2}{|c|}{ Comparision before and after gel injection } & A01 & A05 & A10 & A14 & A23 & A35 \\
\hline \multirow{3}{*}{ Injection pressure (MPa) } & Before & 2.4 & 81 & 6.5 & 7.7 & 5.5 & 6.8 \\
\hline & After & 12.2 & 12 & 12.2 & 12.4 & 12.5 & 6 \\
\hline & Increase value & 9.8 & 3.9 & 5.8 & 4.7 & 7 & - \\
\hline \multirow{3}{*}{$\begin{array}{l}\text { Apparent injectivity index }\left(\mathrm{m}^{3} / \mathrm{d} /\right. \\
\text { Mpa) }\end{array}$} & Before & 11.4 & 102.8 & 104.5 & 90.7 & 107.5 & 122.2 \\
\hline & After & 46.2 & 65 & 89.5 & 62.6 & 50.6 & 127 \\
\hline & Decrease percent & 59.5 & 36.8 & 14.4 & 31 & 52.9 & -- \\
\hline \multicolumn{2}{|l|}{ RF } & 2.3 & 1.5 & 1.3 & 1.5 & 3.6 & Acidification \\
\hline
\end{tabular}

Table 10: Characteristic of gel-injection well effectiveness. 
Citation: Kuiqian Ma, Yanlai Li, Ting Sun (2017) Research and Practice of the Early Stage Polymer Flooding on LD Offshore Oilfield. J Pet Environ Biotechnol 8: 337. doi: 10.4172/2157-7463.1000337

Page 4 of 4

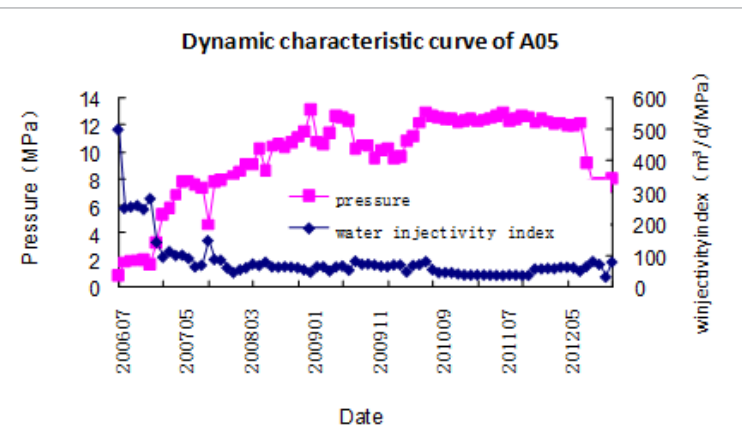

Figure 3: Dynamic characteristic curve of the polymer injector.

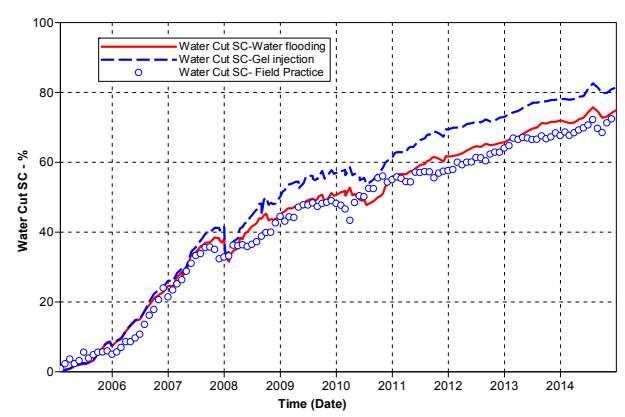

Figure 4: LD field history match curves of water cut.

\section{References}

1. Yanlai L, Yanchun S, Kuiqian M, Qizeng L, Xiaofei J (2011) Study of Gel Flooding Pilot Test and Evaluation Method for Conventional Heavy Oil Reservoir in Bohai Bay. SPE 146617.

2. Xiaodong K, Guozhi F, Xiansongv Z, Fujie S (2007) A method of hall derivative curves to evaluate effects of polymer flooding. China Offshore Oil and Gas 19: $173-175$.

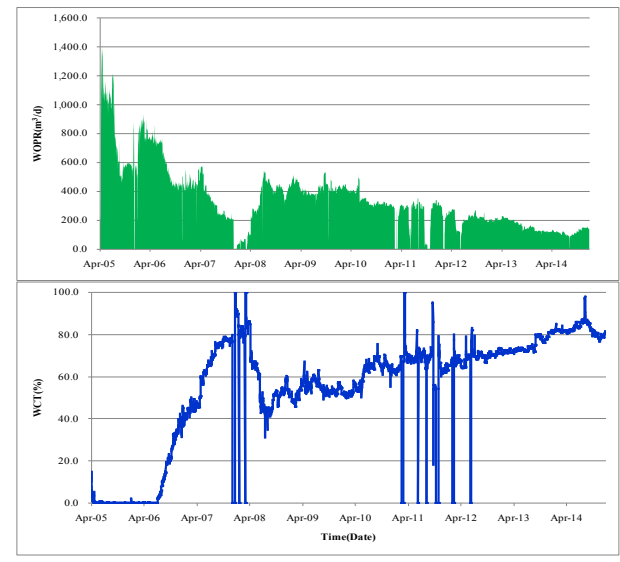

Figure 5: Production curve of producer A11.

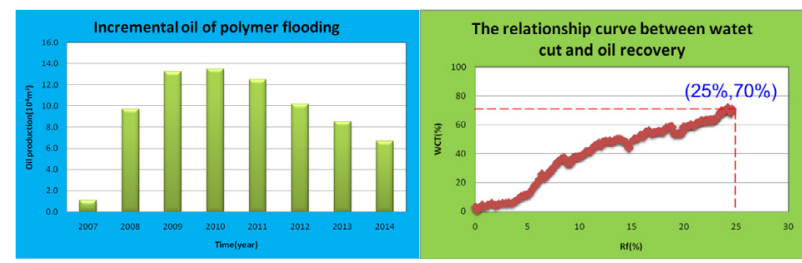

Figure 6: The effectiveness of the early stage polymer flooding.

3. Yanlai L, Yanchun S, Kuiqian M The practice of chemical treatments for heavy oil reservoirs of China offshore oil field WHO C14-196, China.

4. Kuiqian M, Xiaofei J, Jing Y, Yingxian L, Zongbin L (2013) Nitrogen foam flooding test for controlling water cut and enhance oil recovery in conventional oil reservoirs of China offshore oilfield. SPE 165808.

5. Yanchun S, Yanlai L, Lixin T, Kuiqian M, Lilei W (2012) Gel treatments pilot test in conventional heavy oil reservoirs of China offshore oil field. SPE 157762. 